\title{
КОМПЛЕКСНИЙ АНАЛІЗ НАВЧАЛЬНОЇ ЛІТЕРАТУРИ 3 ФАРМАЦЕВТИЧНОГО МЕНЕДЖМЕНТУ ДЛЯ СТУДЕНТІВ ВИЩИХ НАВЧАЛЬНИХ ЗАКЛАДІВ III-IV РІВНІВ АКРЕДИТАЦІї
}

\author{
Б. П. Громовик ${ }^{1}$, А. В. Горілик' \\ ${ }^{1}$ Львівський національний медичний університет імені Данила Галищького, \\ ${ }^{2}$ Національний університет, Лос-Анджелес, Каліфорнія, США

\section{COMPLEX ANANLYSIS OF TEXTBOOKS OF PHARMACEUTICAL MANAGEMENT FOR STUDENTS OF III-IV ACCREDITATION LEVELS UNIVERSITIES} \\ B. P. Hromovyk ${ }^{1}$, A. V. Horilyk ${ }^{1}$, P. V. Hlukhovskyi ${ }^{2}$ \\ ${ }^{1}$ Lviv National Medical University by Danylo Halytskyi, \\ ${ }^{2}$ National University, Los Angeles, California, USA
}

\begin{abstract}
За допомогою авторської методики проведено комплексний аналіз трьох навчальних видань 3 управління у фармації. Обчислення складності їх текстів проводилося за допомогою комп'ютерної програми “Читанка” (http://read.adfarm.com.ua). На підставі якісного аналізу показано, що посібник “Основы и методы управления в фармации” (1986 р.) с базово-формуючим для наступних видань з менеджменту у фармації.
\end{abstract}

A comprehensive analysis of three textbooks in pharmaceutical management was done using the author's technique. The calculation of textbooks readability was conducted with computer program Chytanka (http://read.adfarm.com.ua). Basing on the qualitative analysis, it was shown that "Fundamentals and Methods of Management in Pharmacy" (1986) was the basis for other textbooks in pharmaceutical management.

Вступ. Якість освітнього процесу у вищих навчальних закладах забезпечується кваліфікованим професорсько-викладацьким персоналом, сучасною матеріальною базою, належним методичним забезпеченням та змістовною навчальною літературою: підручниками, навчальними посібниками, практикумами тощо [1]. При цьому оцінка навчальних видань стосовно актуальності, повноти викладу матеріалу, відповідності до навчальної програми завжди була актуальною.

Нами була розроблена методика комплексного аналізу фармацевтичної навчальної літератури, яка включала визначення кількісних і якісних показників та була апробована на прикладі навчальних видань 3 дисципліни “Організація та економіка фармації”. Вказаний підхід дозволив зіставити досліджувані видання за структурою викладу та складністю подання матеріалу [2]. При цьому аналіз навчальної літератури 3 фармацевтичного менеджменту не проводився. Це особливо важливо з погляду еволюції викладання управління у вітчизняній фармацевтичній освіті, основними етапами якої було запровадження у 1978 p. профільного курсу “Основи і методи управління у фармації”, а в 1992 р. навчальної дисципліни “Менеджмент та маркетинг у фармації".

Основна частина. 3 метою виявлення особливостей викладання фармацевтичного менеджменту нами проведено порівняльний аналіз навчальної літератури з даного напрямку:

1) Основы и методы управления в фармации (Р. М. Пиняжко, Б. Л. Парновский, О. Л. Гром, А. Й. Дацко, 1986) - ОМУФ-1986 [3];

2) Менеджмент у фармації (3. М. Мнушко, Н. М. Діхтярьова, 1998) - ММФ-1998 [4];

3) Менеджмент у фармації (О. Є. Кузьмін, Б. П. Громовик, Г. Д. Гасюк, О. Р. Левицька, О. Г. Мельник, 2009) - МФ-2009 [5].

Для уніфікації даних про обсяг матеріалу, викладеного в аналізованій літературі, замість кількості сторінок використовували кількість умовних друкованих аркушів (УДА). Як видно з даних таблиці 1, обсяг основного тексту найновішого видання (МФ-2009) значно перевищує попередні два. Під основним текстом ми розуміємо обсяг матеріалу, викладеного у

( Б. П. Громовик, А. В. Горілик, П. В. Глуховський 
підручнику без врахування завдань для самостійної роботи та додатків.

Виявлено, що із засобів для навігації архітектоні- кою підручника у ММФ-1998 наявний лише зміст, на противагу виданням ОМУФ-1986 та МФ-2009 із предметним покажчиком та глосарієм відповідно.

Таблиця 1. Зведений огляд результатів кількісного аналізу навчальних видань 3 управління у фармації

\begin{tabular}{|c|c|c|c|}
\hline $\begin{array}{r}\text { Показники } \\
\end{array}$ & ОМУФ-1986 & ММФ-1998 & МФ-2009 \\
\hline $\begin{array}{l}\text { 1. Бібліографічні дані } \\
\text { 1.1. Кількість сторінок } \\
\text { 1.2. Формат паперу } \\
\text { 1.3. Коефіцієнт переведення } \\
\text { 1.4. Кількість УДА } \\
\text { 1.5. К-сть УДА основного тексту }\end{array}$ & $\begin{array}{c}352 \\
84 \times 108_{1 / 32} \\
1,68 \\
\mathbf{1 8 , 4 8} \\
\mathbf{1 7 , 8 5}\end{array}$ & $\begin{array}{c}255 \\
60 \times 90_{1 / 16} \\
1,0 \\
\mathbf{1 5 , 9 4} \\
\mathbf{1 5 , 0 0}\end{array}$ & $\begin{array}{c}432 \\
70 \times 100_{1 / 16} \\
1,30 \\
\mathbf{3 5 , 1 0} \\
\mathbf{2 6 , 8 1}\end{array}$ \\
\hline $\begin{array}{l}\text { 2. Засоби для навігації архітектонікою підручника } \\
\text { 2.1. Зміст } \\
\text { 2.2. Предметний покажчик } \\
\text { 2.3. Глосарій }\end{array}$ & $\begin{array}{l}+ \\
+ \\
-\end{array}$ & $\begin{array}{l}+ \\
- \\
-\end{array}$ & $\begin{array}{l}+ \\
- \\
+\end{array}$ \\
\hline 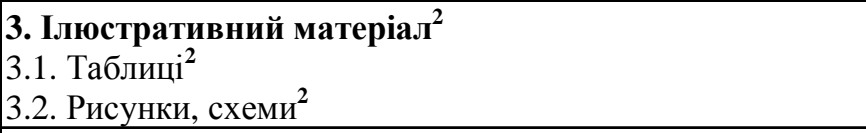 & $\begin{array}{l}0,95 \\
1,23 \\
\end{array}$ & $\begin{array}{l}0,47 \\
2,07 \\
\end{array}$ & $\begin{array}{l}1,60 \\
3,43 \\
\end{array}$ \\
\hline $\begin{array}{l}\text { 4. Перелік рекомендованої (використаної) літератури } \\
\text { 4.1. Законодавство } \\
\text { 4.2. Авторські публікації } \\
\text { 4.3. Інші джерела }\end{array}$ & $\begin{array}{c}- \\
2 \\
38\end{array}$ & $\begin{array}{c}21 \\
3 \\
71\end{array}$ & $\begin{array}{c}20 \\
22 \\
143\end{array}$ \\
\hline $\begin{array}{l}\text { 5. Самостійна робота } \\
\text { 5.1. Контрольні запитання } \\
\text { 5.2. Практичні завдання } \\
\text { 5.3. Тестові запитання }\end{array}$ & $\begin{array}{l}51 \\
- \\
-\end{array}$ & $\begin{array}{c}140 \\
- \\
-\end{array}$ & $\begin{array}{l}201 \\
22 \\
90\end{array}$ \\
\hline
\end{tabular}

Примітки: 1 -іменний покажчик, бланки та форми відсугні; 2 - питома насиченість рисунками, таблицями тощо на 1 УДА основного тексту; 3 - самоцитування; 4 - к-сть у натуральному показнику.

\section{Джерело: власне опрацювання.}

Усі аналізовані навчальні видання ілюстровані рисунками, схемами та таблицями. При цьому, якщо підручники ОМУФ-1986 та ММФ-1998 схожі за насиченням вказаними матеріалами, то у ММФ-1998 відбувається перерозподіл ілюстративного матеріалу в бік зменшення кількості таблиць та зростання кількості схем і рисунків. Виклад навчального матеріалу у підручнику МФ-2009 характеризується значно більшим насиченням таблицями, рисунками i схемами.

Варто відзначити, що усі навчальні видання вміщують переліки рекомендованої літератури. Очевидно, що автори флагманського посібника з управління у фармації (ОМУФ-1986) не мали змоги включити до такого переліку посилання на нормативно-правові акти, проте в період видання новіших підручників така законодавча база вже була напрацьована.

Самостійна робота студента є дуже важливим чинником фахового зростання, то ж маємо відмітити, що принаймні контрольні питання для самоперевірки містять усі аналізовані видання. Окрім цього, підручник МФ-2009 вміщує 22 практичних завдання з при- кладами їх вирішень, а також 90 тестів з ключами відповідей. Додатки в усіх навчальних виданнях відсутні.

За допомогою авторської комп'ютерної програми “Читанка" (http://read.adfarm.com.ua) проведено розрахунок п'яти індексів читабельності: туманності Ганнінга $\left(I_{f o g}\right)$, Флеща-Кінкейда $(F), \operatorname{SMOG}\left(I_{S M O G}\right)$, Колеман-Лiу $\left(I_{C L}\right)$ та автоматизованого індексу читабельності $\left(I_{C L}\right)$. В результаті проведеного дослідження за показником середнього індексу читабельності $\left(I_{A V G}\right)$ встановлено, що складнішим для сприйняття відносно інших видань $€$ посібник ОМУФ-1986 (табл. 2), що можна пояснити піонерським запровадженням низки нових управлінських термінів та управлінських технологій щодо фармацевтичної системи в авторському трактуванні, які в подальшому пройшли процес адаптування та доопрацювання.

В результаті якісного аналізу викладеного матеріалу встановлено, що архітектоніка посібника ОМУФ1986 була добре продумана авторами, позаяк усі теми увійшли до видань наступних десятиліть: ММФ-1998 та МФ-2009 (рис. 1). 
Таблиця 2. Результати визначення читабельності тексту підручників

\begin{tabular}{|c|c|c|c|}
\hline \multirow{2}{*}{ Показники } & \multicolumn{3}{|c|}{ Підручники } \\
\cline { 2 - 4 } & ОМУФ-1986 & ММФ-1998 & МФ-2009 \\
\hline$I_{\text {fog }}$ & 31,75 & 30,17 & 28,94 \\
\hline$F$ & 29,30 & 25,14 & 24,24 \\
\hline$I_{S M O G}$ & 21,99 & 22,64 & 22,02 \\
\hline$I_{A R I}$ & 23,53 & 20,77 & 19,84 \\
\hline$I_{C L}$ & 27,62 & 21,95 & 20,93 \\
\hline$I_{A V G}$ & $\mathbf{2 6 , 8 4}$ & $\mathbf{2 4 , 1 3}$ & $\mathbf{2 3 , 1 9}$ \\
\hline
\end{tabular}

Джерело: власне опрацювання.

Основы и метолы управ.тения в фармацин-1986

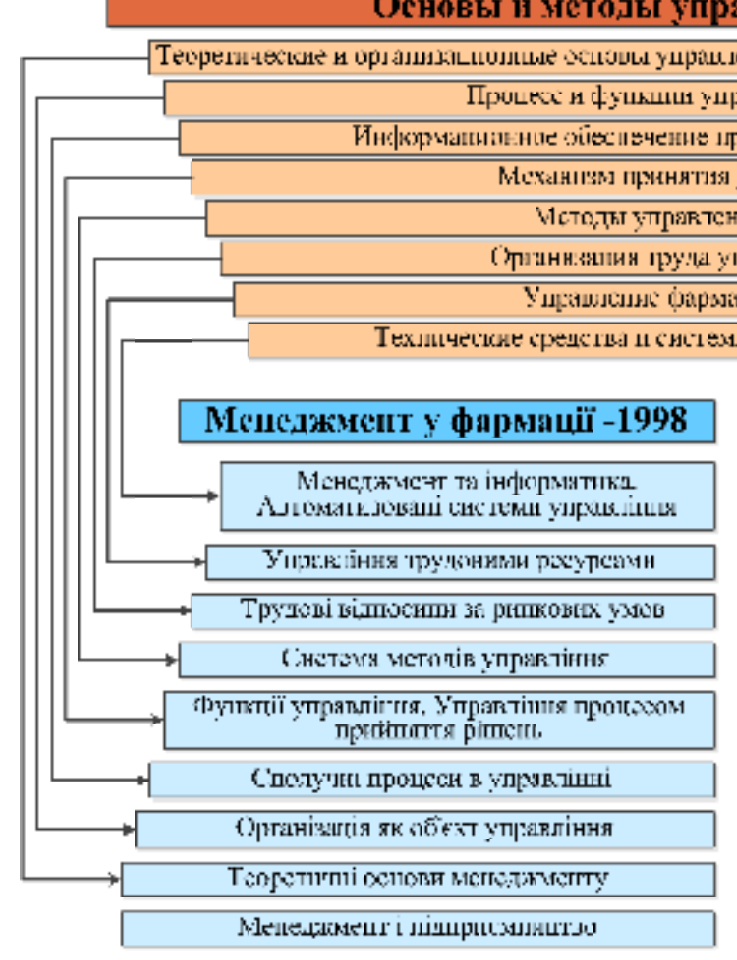

Puc. 1. Розподіл матеріалу, поданого у навчальних виданнях з управління у фармації, за темами.

Джерело: власне опрацювання.

Таким чином, базово-формуючим з менеджменту у фармації можна вважати посібник ОМУФ-1986. Звичайно, що на вимогу часу, з розвитком ринкових відносин, певний матеріал повинен був трансформуватися та актуалізуватися. Так, принципи управління при соціалізмі (з першого розділу ОМУФ-1986) більше не розглядаються, натомість подаються теми: "Менеджмент і підприємництво” (ММФ-1998) та “Суб”єкти фармацевтичного підприємництва” (МФ-2009).

Методи фармацевтичного менеджменту достатньо широко описані в ОМУФ-1986 (4,4 УДА) та МФ2009 (2,1 УДА), а у виданні ММФ-1998 аналогічна тематика викладена всього на 0,6 УДА. У підручнику МФ-2009 додатково розглядається тема "Керівництво та лідерство у фармацевтичних організаціях", яка відсутня в двох інших виданнях.
Висновки. За допомогою авторської методики та iї складової - комп'ютерної програми “Читанка" проаналізовано кількісні та якісні показники трьох навчальних видань 3 менеджменту у фармації. Отримано порівняння відповідності до рівня читацької аудиторії бібліографічних даних і друкарської інформації, засобів навігації архітектонікою навчальних видань, насиченості ілюстративним матеріалом, переліку рекомендованої літератури, наявності завдань для самостійної роботи, змісту довідкових матеріалів, читабельності тексту.

На підставі якісного аналізу встановлено, що посібник "Основы и методы управления в фармации" (Р. М. Пиняжко и соавт., 1986) є базово-формуючим з менеджменту у фармації, позаяк усі його теми увійшли до наступних навчальних видань. 


\section{Лiтература}

1. Громовик Б. П. До питання забезпечення навчальною літературою профільної дисципліни організаційно-економічного спрямування / Б. П. Громовик, С. I. Терещук // Пріоритети організаційно-економічної науки та освіти у розвиткувітчизняної фармації : матеріали наук.-практ. конф. - Харків : Вид-во НфаУ, 2005. - С. 16-18.

2. Горілик А. В. Розробка методики порівняльного комплексного аналізу навчальної літератури (на прикладі дисципліни “Організація та економіка фармації') / А. В. Горілик, Б. П. Громовик, П. В. Глуховський // Український медичний альманах. -2012. - Т. 15, № 5, дод. 1. -С. 82-85.
3. Основы и методы управления в фармации : [учеб. пособие для для высш. уч. зав.] / Р. М. Пиняжко, Б. Л. Парновский, О. Л. Гром, А. Й. Дацко. - К. : Вища школа, 1986. $351 \mathrm{c}$.

4. Мнушко 3. М. Менеджмент та маркетинг у фармації. Ч. I: Менеджмент у фармації / 3. М. Мнушко, Н. М. Діхтярьова ; за ред. 3. М. Мнушко. - Харків : Основа, 1998. - 255 с.

5. Менеджмент у фармації: підручник [для вищ. навч. закл.] / [О. Є. Кузьмін, Б. П. Громовик, Г. Д. Гасюк та ін.], за ред. О. С. Кузьміна і Б. П. Громовика. - [2-ге вид.]. - Вінниця : Нова книга, 2009. -432 с. 